\title{
KNOWLEDGE, ATTITUDE AND PRACTICE OF EAR CARE AMONG PRE CLINICAL MEDICAL STUDENTS AT BIRAT MEDICAL COLLEGE TEACHING HOSPITAL
}

\author{
Koirala $B^{1^{*}}$, Manandhar $S^{2}$, Shah $R K^{3}$
}

\begin{abstract}
Affiliation
1. Lecturer, Department of ENT and HNS, Birat Medical College and Teaching Hospital

2. Associate professor, Department of ENT and HNS, Birat Medical College and Teaching Hospital

3. Assistant Professor, Department of ENT and HNS, Birat Medical College and Teaching Hospital
\end{abstract}

\section{ARTICLE INFO}

Received : 23 November, 2020

Accepted : 22 December, 2020

Published : 31 December, 2020

(C) Authors retain copyright and grant the journal right of first publication with the work simultaneously licensed under Creative Commons Attribution License CC - BY 4.0 that allows others to share the work with an acknowledgment of the work's authorship and initial publication in this journal.

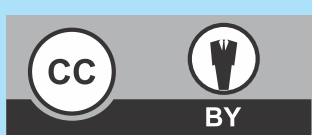

ORA 214

DOI: https://doi.org/10.3126/bjhs.v5i3.33705

\section{* Corresponding Author \\ Dr. Bipin Koirala \\ Lecturer \\ Department of ENT and HNS}

Birat Medical College and Teaching Hospital, Biratnagar

Email ID: koirala875@gmail.com

ORCID ID: https://orcid.org/0000-0002-2743-5245

\section{Citation}

Koirala B, Manandhar S, Shah RK. Knowledge, Attitude and Practice of Ear Care among Pre Clinical Medical Students at Birat Medical College Teaching Hospital. BJHS 2020;5(3)13. 1236-1240.

\section{ABSTRACT}

\section{Introduction}

Ear care is a part of social cleanliness. It may not demand much care but proper and adequate care is essential to protect the optimal functions. The knowledge and awareness of ear care practice however is still lacking. Non-hygienic individual behaviors and habits like penetrating foreign objects, exposure to loud noise may affect the human ear. Lack of proper ear care may lead to many diseases and its complications.

\section{Objectives}

To assess the knowledge attitude and practice of ear care of pre clinical medical students attending Birat Medical College.

To correlate the knowledge, attitude and practice of ear care of pre clinical medical students.

\section{Methodology}

A descriptive cross sectional study was done in 151 students of pre clinical sciences of Birat Medical College for a period of two months from $15^{\text {th }}$ September to $15^{\text {th }}$ November, 2020. After the ethical clearance a specifically designed semi structured questionnaire containing yes and no questions was prepared in google form and distributed among all the pre clinical medical students of Birat Medical College Teaching Hospital students and then their response was evaluated.

\section{Result}

Students of pre clinical sciences had good knowledge, attitude and practice of ear care. Significant correlation was seen between knowledge and practice and also between knowledge and attitude. However there was no significant correlation between attitude and practice.

\section{Conclusion}

Overall knowledge, attitude and practice of preclinical medical students of Birat Medical College was good. Surprisingly students showed poor knowledge, attitude and practice in few individual questionnaires which was hoped that the medical students know more than non medical individual in the society.

\section{KEYWORD}

Attitude, ear care, knowledge, practice, pre clinical 


\section{INTRODUCTION}

Ear is a necessary organ that helps us to hear as well as maintain body balance. Ear care is a part of social cleanliness. ${ }^{1}$ It may not demand much care but proper and adequate care is essential to protect its optimal functions. The knowledge and awareness of ear care practice however is still lacking. Non-hygienic individual behaviors and habits like penetrating foreign objects, exposure to loud noise may affect human ear.

Wax plays an important role in ear care. Wax is a result of combined secretions of ceruminous sebaceous glands and desquamated epithelium from tympanic membrane and external auditory canal. ${ }^{2}$ Specific amount of wax is useful for keeping and maintaining healthy ears. It protects, cleans and lubricates the skin of ear canal. ${ }^{3}$ Normally canal has selfcleansing mechanism and it doesn't need to be cleaned. However, people use several objects such as cotton buds and pins to clean and discard the wax. Use of such objects may penetrate and perforate tympanic membrane. Exposure to loud noise in sudden situations such as explosions or heavy constructions could lead to hearing loss. Less sharp sound if exposed over a long time period may also cause hearing loss. ${ }^{4}$ Ear infection, Diabetes mellitus, hypertension, excessive use of mobile phone or listening to music at high volume all can cause reduced hearing. High proportion of population do not realize the unhygienic practice due to the lack of knowledge and attitude which are associated with majority of ear disorders. In developing countries, ear diseases are considered a serious public health problem. Human activities and practices that are not hygienic can affect the human ear. Lack of proper ear care may lead to many diseases and its complications. This type of study would be valuable to know about the knowledge, attitude and practice of ear care in the pre clinical medical students so to plan the awareness programs accordingly so as to improve the knowledge, attitude and practice for hygienic and proper ear care. Also there has been no published literature of this kind in this setting.

This study was thus undertaken to assess the knowledge, attitude and practice of ear care of pre clinical medical students attending Birat Medical College and to correlate the knowledge, attitude and practice of ear care of pre clinical medical students

\section{METHODOLOGY}

This is a prospective, descriptive cross sectional study done for a period of two months from $15^{\text {th }}$ September to $15^{\text {th }}$ November, 2020. After the ethical clearance a specifically designed semi structured questionnaire containing yes and no questions was prepared in google form and distributed among all 151 pre clinical medical students of Birat Medical College Teaching Hospital students and then their response was evaluated. Questionnaires were specifically designed to assess the knowledge, practice as well as attitude. (Table1)
Table1: Questionnaires to assess knowledge, attitude and practice.

\begin{tabular}{|l|l|}
\hline \multicolumn{2}{|c|}{ Questionnaires directed to asses knowledge were } \\
\hline 1. & Should wax be removed continuously? \\
\hline 2. & Does perforations in ear require surgery? \\
\hline 3. & $\begin{array}{l}\text { Sudden exposure to loud noise can damage } \\
\text { your hearing ability. }\end{array}$ \\
\hline 4. & $\begin{array}{l}\text { I require medical consultation and help because } \\
\text { of poor hearing ability. }\end{array}$ \\
\hline 5. & High and low altitude may cause ear pain. \\
\hline Questionnaires directed to asses practice \\
\hline 1. & $\begin{array}{l}\text { I have habit of ear cleaning } \\
\text { like pencils, pins,ear buds etc. }\end{array}$ \\
\hline 2. & $\begin{array}{l}\text { Normally I blow my nose roughly when I have cold } \\
\text { or influenza }\end{array}$ \\
\hline 3. & $\begin{array}{l}\text { I normally use ear drops without doctor } \\
\text { consultation when I have an ear pain }\end{array}$ \\
\hline 4. & $\begin{array}{l}\text { I use headsets when listening to loud music for } \\
\text { long period of time }\end{array}$ \\
\hline 5. & I use oils in ear. \\
\hline Questionnaires directed to asses attitude were \\
\hline 1. & I believe exposure to loud noise causes deafness \\
\hline 2. & I recommend to put water while bathing. \\
\hline 3. & $\begin{array}{l}\text { Ear piercing must be done as early as possible } \\
\text { from birth. }\end{array}$ \\
\hline 4. & I should visit my ENT specialist in certain interval \\
\hline 5. & $\begin{array}{l}\text { I realize the importance of neonatal screening for } \\
\text { hearing status }\end{array}$ \\
\hline
\end{tabular}

\section{RESULT}

Pre-designed specific questionnaires were given to 151 students of pre clinical sciences. The overall knowledge, attitude and practice were analyzed. Students who scored three or more were labeled to have good knowledge, attitude and practice and who scored less than three were considered to have poor knowledge, attitude and practice. Among 151 students, 78 were males and 73 were females.

Around $49.67 \%$ of students did not have the knowledge that wax should not be removed continuously. Majority of the students(84.8\%) had knowledge that sudden exposure to loud noise may damage hearing ability and similarly 99.33\% of students know about the requirement of medical consultation if hearing ability is poor. Around $95.36 \%$ of students know that high and low altitude may cause ear pain Majority of the students (91.39\%) believed that exposure to loud noise cause deafness. Most of them also realized the importance of neonatal screening for hearing (91.39\%). They also realized the importance to visit ENT specialist at regular interval (76.82\%). Around $72.85 \%$ think that ear piercing must be done as early as possible. Around $57.62 \%$ of students have the habit of blowing nose regularly when they have cold or influenza. Around $24.5 \%$ of students have habit of using sharp objects like pencils, pins and ear buds to clean ear. (Table2) 
T able 2: Response of students of pre clinical students.

\begin{tabular}{|l|l|l|}
\hline \multicolumn{1}{|c|}{ Questionnaire } & Yes $\mathrm{n}(\%)$ & \multicolumn{1}{|c|}{ No $\mathrm{n}(\%)$} \\
\hline Should wax be removed continuously? & $75(49.67)$ & $76(50.33)$ \\
\hline $\begin{array}{l}\text { I have habit of ear cleaning with sharp } \\
\text { objects like pencils,pins,ear buds etc }\end{array}$ & $37(24.5)$ & $114(75.5)$ \\
\hline Does perforations in ear require surgery? & $63(41.72)$ & $88(58.28)$ \\
\hline $\begin{array}{l}\text { I believe exposure to loud noise causes } \\
\text { deafness. }\end{array}$ & $138(91.39)$ & $13(8.61)$ \\
\hline $\begin{array}{l}\text { Normally I blow my nose roughly when I } \\
\text { have cold or influenza }\end{array}$ & $87(57.62)$ & $64(42.38)$ \\
\hline $\begin{array}{l}\text { I normally use ear drops without doctor } \\
\text { consultation when I have an ear pain }\end{array}$ & $11(7.28)$ & $140(92.72)$ \\
\hline $\begin{array}{l}\text { I use headsets when listening to loud music } \\
\text { for long period of time }\end{array}$ & $48(31.79)$ & $103(68.21)$ \\
\hline I recommend to put water while bathing. & $27(17.88)$ & $124(82.12)$ \\
\hline $\begin{array}{l}\text { Ear piercing must be done as early as } \\
\text { possible from birth. }\end{array}$ & $41(27.15)$ & $110(72.85)$ \\
\hline $\begin{array}{l}\text { Sudden exposure to loud noise can damage } \\
\text { your hearing ability. }\end{array}$ & $128(84.8)$ & $23(15.2)$ \\
\hline $\begin{array}{l}\text { I should visit my ENT specialist in certain } \\
\text { interval. }\end{array}$ & $116(76.82)$ & $35(23.18)$ \\
\hline $\begin{array}{l}\text { I require medical consultation and help } \\
\text { because of poor hearing ability }\end{array}$ & $150(99.34)$ & $1(0.66)$ \\
\hline I recommend oils to be used in ear. & $49(32.45)$ & $102(67.55)$ \\
\hline $\begin{array}{l}\text { I realize the importance of neonatal } \\
\text { screening for hearing status. }\end{array}$ & $138(91.39)$ & $13(8.61)$ \\
\hline High and low altitude may cause ear pain. & $144(95.36)$ & $7(4.64)$ \\
\hline
\end{tabular}

Students of pre clinical sciences had good knowledge, attitude and practice of ear care. (Table2)

Table 3: Knowledge, attitude and practice of students ofpre clinical sciences.

\begin{tabular}{|l|l|l|c|}
\hline \multicolumn{1}{|c|}{} & Good (\%) & Poor (\%) & Total \\
\hline Knowledge & $131(86.75)$ & $20(13.25)$ & 151 \\
\hline Attitude & $147(97.35)$ & $4(2.65)$ & 151 \\
\hline Practice & $125(82.78)$ & $26(17.22)$ & 151 \\
\hline
\end{tabular}

The correlation between demographics with knowledge, attitude and practice were investigated. (Table 4,5,6). Significant correlation ( $p$ value $=0.01$ ) was seen between religion and knowledge. However, other demographics had no correlation with knowledge, attitude and practice.

\begin{tabular}{|c|c|c|c|c|}
\hline Demographics & $\begin{array}{c}\text { Good } \\
\text { knowledge } \\
\text { (n=131) }\end{array}$ & $\begin{array}{c}\text { Poor } \\
\text { knowledge } \\
(\mathrm{n}=20)\end{array}$ & Total & $P$ value \\
\hline \multicolumn{5}{|l|}{ Country } \\
\hline Nepal & 87 & 13 & 100 & \multirow[t]{2}{*}{0.9} \\
\hline India & 44 & 7 & 51 & \\
\hline \multicolumn{5}{|l|}{ Religion } \\
\hline Hindu & 120 & 17 & 137 & \multirow[t]{4}{*}{0.4} \\
\hline Muslim & 5 & 2 & 7 & \\
\hline Christian & 3 & 1 & 4 & \\
\hline Buddhist & 3 & 0 & 3 & \\
\hline
\end{tabular}

Table 5: Correlation between attitude and demographics

\begin{tabular}{|c|c|c|c|c|}
\hline Demographics & $\begin{array}{c}\text { Good } \\
\text { attitude } \\
(n=147)\end{array}$ & $\begin{array}{c}\text { Poor } \\
\text { attitude } \\
(n=4)\end{array}$ & Total & P value \\
\hline \multicolumn{5}{|l|}{ Country } \\
\hline Nepal & 96 & 4 & 100 & \multirow[t]{2}{*}{0.3} \\
\hline India & 51 & 0 & 51 & \\
\hline \multicolumn{5}{|l|}{ Religion } \\
\hline Hindu & 134 & 3 & 137 & \multirow[t]{4}{*}{0.01} \\
\hline Muslim & 7 & 0 & 7 & \\
\hline Christian & 4 & 0 & 4 & \\
\hline Buddhist & 2 & 1 & 3 & \\
\hline
\end{tabular}

Table 6: Correlation between practice and demographics

\begin{tabular}{|c|c|c|c|c|}
\hline Demographics & $\begin{array}{c}\text { Good } \\
\text { practice } \\
(n=125)\end{array}$ & $\begin{array}{c}\text { Poor } \\
\text { practice } \\
(n=26)\end{array}$ & Total & P value \\
\hline \multicolumn{5}{|l|}{ Country } \\
\hline Nepal & 84 & 16 & 100 & \multirow[t]{2}{*}{0.5} \\
\hline India & 41 & 10 & 51 & \\
\hline \multicolumn{5}{|l|}{ Religion } \\
\hline Hindu & 114 & 23 & 137 & \multirow[t]{4}{*}{0.8} \\
\hline Muslim & 6 & 1 & 7 & \\
\hline Christian & 3 & 1 & 4 & \\
\hline Buddhist & 2 & 1 & 3 & \\
\hline
\end{tabular}

Significant correlation was seen between knowledge and practice and also between knowledge and attitude. However there was no significant correlation between attitude and practice.

Table 7: Correlation between knowledge and practice of students of pre clinical sciences.

\begin{tabular}{|l|l|c|c|c|c|}
\hline & & \multicolumn{2}{|c|}{ Practice } & & P value \\
\hline \multirow{2}{*}{ Knowledge } & & Good & Poor & Total & \\
\cline { 2 - 6 } & Pood & 116 & 15 & 131 & 0.0 \\
\hline Total & & 9 & 11 & 20 & \\
\hline
\end{tabular}

Table 8: Correlation between knowledge and attitude of students of pre clinical sciences.

\begin{tabular}{|c|c|c|c|c|c|}
\hline & & \multicolumn{2}{|c|}{ Attitude } & & \multirow[t]{2}{*}{$P$ value } \\
\hline & & Good & Poor & Total & \\
\hline \multirow[t]{2}{*}{ Knowledge } & Good & 129 & 2 & 131 & \multirow[t]{2}{*}{0.02} \\
\hline & Poor & 18 & 2 & 20 & \\
\hline Total & & 147 & 4 & 151 & \\
\hline
\end{tabular}

Table 9: Correlation between knowledge and attitude of students of pre clinical sciences.

\begin{tabular}{|l|l|l|l|l|l|}
\hline & & \multicolumn{2}{|c|}{ Practice } & & P value \\
\hline \multirow{2}{*}{ Attitude } & & Good & Poor & Total & \\
\cline { 2 - 6 } & Good & 122 & 25 & 147 & 0.5 \\
\cline { 2 - 5 } & Poor & 3 & 1 & 4 & \\
\hline Total & & $\mathbf{1 2 5}$ & $\mathbf{2 6}$ & $\mathbf{1 5 1}$ & \\
\hline
\end{tabular}




\section{DISCUSSION}

The ear is an important organ responsible for hearing and balance mechanism. It produces lubricating ear wax which protects the ear. Many people tend to remove wax and have habits of inserting different objects like cotton buds, sticks as well as oil or water in ear which may lead to complications. In the present study, we assessed knowledge, attitude and practice of pre clinical medical students.

Ear protects and cleans itself by process of cerumen production and by the epithelial migration from inside to outward that traps dirt by hairs present in skin lining of the outer one third of ear. Around $50.33 \%$ of students had the knowledge that the wax should not be removed continuously. Around $76.82 \%$ of students had an attitude to visit ENT specialist for ear care and cleanliness. However, $24.5 \%$ of students had the habit of cleaning ear with objects like cotton buds, pencils. Probable explanation for this could be some degree of dexterity in cleanliness. Afolabi et al, Amutta et al, Olajide et al and Hobson et al in their study found higher percentage of people practicing the ear cleanliness by inserting objects $(90 \%, 80 \%, 92.8 \%$ and $68 \%$ respectively). ${ }^{2,6,8}$ This difference could be due to the difference in study population. They studied in community while the present study was done in pre clinical medical students. Thus, this study doesn't give true estimation of community prevalence.

Surprisingly pre clinical medical students didn't know perforation in ear require surgery. Proper education is required as their knowledge is important to educate the people in community in community health programs.

Excessive exposure to loud noise causes symptoms like tinnitus and consecutive hearing loss. In the present study 91.39\% believed that loud noise caused deafness but $31.79 \%$ of students still despite knowing the fact use headsets and listen to loud noise for long period of time. Similar finding was found in study by Clark. ${ }^{10}$ This could be due the fact that rather than other noisy sounds popular music is enjoyed at high volume before it becomes disturbing. Miyake et al illustrated the risk of using headphones to listen to loud music. ${ }^{11}$

Students had a very good knowledge about the damage to the hearing ability by loud sound and ear ache due to high and low altitude. Low atmospheric pressure, hypoxia, dry cold weather is present in high altitude which results in sudden hearing loss, tinnitus, dizziness, aural fullness and otalgia. ${ }^{12}$ Belief of early ear piercing seen in $72.85 \%$ of students could be due to the misconception that is prevalent in the society. In this present study very few students (7.28\%) practiced to put ear drops without consultation when they have ear pain. Contrary to this in the study done by Dosemanne et al. ${ }^{5}$ Around $44.8 \%$ - $66.9 \%$ of patients put drops available at home in ear when they have pain or discharge. This difference could be due to the attitude of the patient to visit ear specialist frequently and the study population being students of pre clinical medical sciences. Even few students who practiced this should be made aware about the adverse effects of using ear drops indiscriminately. To our knowledge there are no similar studies in the literature. Around $57.62 \%$ of the students have a habit of blowing nose roughly when they have cold or influenza. Incidence was high $75.2 \%$ in study done by Costal Karnataka Dosemanne et al. ${ }^{5}$ In the present study $67.55 \%$ of students didn't use oils in ear as this practice aggravates ear disorders like acute suppurative otitis media and chronic suppurative otitis media leading to intracranial and intratemporal complications.

Most of the students, $91.39 \%$ of students knew about the importance of neonatal screening for hearing status. This attitude could be helpful to them in analyzing the hearing ability in neonates especially in congenital disorders.

Our study showed that the pre clinical students had good knowledge, attitude and practice of ear care. Contrary to this in the study by Adeyi et al, the health professionals had poor knowledge and attitude towards ear care practice. ${ }^{13}$ This discrepancy could be due to the questionnaire used. They used a validated questionnaire and included all the medical professionals (not only students) in their study.

Knowledge, attitude and practice were correlated with demographics of pre clinical medical students. Present study showed religion had influence on attitude. Compared to other religion Hindu recommended putting water in ear while bathing. Contrary to this study by Aldawsari et al showed no significance between demographics and attitude. ${ }^{3}$ This difference could be due to difference in questionnaire used. Knowledge and practice did not correlate with demographics in this study. On reviewing literatures not much study has been done correlating knowledge and practice.

Our study showed that attitude and practice was significantly influenced by knowledge. This study was similar to study done by Aldasweri et al. ${ }^{3}$

\section{CONCLUSION}

Overall knowledge, attitude and practice of preclinical medical students of Birat Medical College was good. Surprisingly students showed poor knowledge, attitude and practice in few individual questionnaires which was expected that the medical students know more than non medical individuals in the society.

\section{RECOMMENDATIONS}

Majority of the ear diseases can be prevented by a proper ear care. Hence simple awareness programs would diminish these problems thereby reducing considerable morbidity. More courses and programs should be implemented about knowledge, attitude and practice. 


\section{LIMITATIONS OF THE STUDY}

Study was conducted in pre clinical students of single medical college hence the result cannot be generalized. This study doesn't give true estimation of community prevalence.

\section{ACKNOWLEDGEMENT}

We are grateful to all the participants of this study. Our special thanks to Dr Neeta Kafle and Dr Ram Kumar Mehta for their help in data collection and management.

\section{CONFLICT OF INTEREST}

None

\section{REFERENCES}

1. Adoga AA, Nimkur TL. Acute otitis media complicating upper respiratory tract infection: Knowledge and treatment outcomes in health professionals. J Med Trop. 2013 Jul 1;15(2):135.

2. Amutta SB, Yunusa MA, Iseh KR, Obembe A, Egili E, Aliyu D, et al. Sociodemographic Characteristics and Prevalence of Self Ear Cleaning in Sokoto Metropolis. Int J Otolaryngol Head Neck Surg. 2013 Nov 11;2(6):720-6.DOI: 10.4236/ijohns.2013.26057

3. Aldawsari SA, Aldawsari AA, Aljthalin AA, AIDossari FM, Alhammad MA, Shatri MSA, et al. Knowledge, Attitudes and Practices of Self-Ear Cleaning Among Medical Students, Majmaah University, Saudi Arabia. :7. DOI:10.21276/ijmrp

4. Alateeq OM, Alwassel Al, Almuhaini MS. Knowledge, Attitude and Practice of Ear Care in Saudi Community. J Middle East North Afr Sci. 2018 Feb;4(2):42-4.DOI:10.12816/0045063

5. Dosemane D, Ganapathi K, Kanthila J. Knowledge, Attitude and Practice of Ear Care in Coastal Karnataka. J Clin Diagn Res JCDR. 2015 Dec;9(12):MC01-4.DOI: 10.7860/JCDR/2015/15401.6880

6. Afolabi AO, Kodiya AM, Bakari A, Ahmad BM. Attitude of self ear cleaning in black Africans: any benefit? East Afr J Public Health. 2009 Apr;6(1):43-6DOI:10.4314/eajph.v6i1.45743.
7. Olajide GT, Usman AM, Eletta PA. Knowledge, Attitude and Awareness of Hazards Associated with Use of Cotton Bud in a Nigerian Community. Int J Otolaryngol Head Neck Surg. 2015;04(03):248.DOI:10.4236/ijohns.2015.43042

8. Hobson JC, Lavy JA. Use and abuse of cotton buds. J R Soc Med. 2005 Aug;98(8):360-1.DOI:10.1258/jrsm.98.8.360

9. Zhao F, French D, Manchaiah VK, Liang M, Price SM. Music exposure and hearing health education: A review of knowledge, attitude, and behaviour in adolescents and young adults. Health Educ J. 2012 Nov 1;71(6):709-24.DOI:10.1177/0017896911422780

10. Clark WW. Noise exposure from leisure activities: a review. J Acoust Soc Am. 1991 Jul;90(1):175-81.DOI:10.1121/1.401285

11. Miyake S, Kumashiro M. Effects of listening to music with headphones on hearing--especially under noisy conditions. J UOEH. 1986 Dec 1;8(4):391-404.DOI:10.7888/juoeh.8.391

12. Dursun E. Otologic effects of environmental conditions at highaltitude. Internet J Otorhinolaryngol. 2008 Dec 31;11(1).

13. Adeyi A, Tonga N. Ear care: Knowledge, attitude and practice amongst health professionals at the Jos university teaching hospital. East Afr J Public Health. 2013 Jan 1;10.DOI:10.4103/2276-7096. 123600 